\title{
Volcanic Ash and Aviation-The Challenges of Real-Time, Global Communication of a Natural Hazard
}

\author{
Peter Lechner, Andrew Tupper, Marianne Guffanti, \\ Sue Loughlin and Tom Casadevall
}

\begin{abstract}
More than 30 years after the first major aircraft encounters with volcanic ash over Indonesia in 1982, it remains challenging to inform aircraft in flight of the exact location of potentially dangerous ash clouds on their flight path, particularly shortly after the eruption has occurred. The difficulties include reliably forecasting and detecting the onset of significant explosive eruptions on a global basis, observing the dispersal of eruption clouds in real time, capturing their complex structure and constituents in atmospheric transport models, describing these observations and modelling results in a manner suitable for aviation users, delivering timely warning messages to the cockpit, flight planners and air traffic management systems, and the need for scientific development in order to undertake operational enhancements. The framework under which these issues are managed is the International Airways Volcano Watch (IAVW), administered by the International Civil Aviation Organization (ICAO). ICAO outlines in its standards and recommended practices (International Civil Aviation Organization 2014a, b) the basic volcanic monitoring and communication that is necessary at volcano observatories in Member States (countries). However, not all volcanoes are monitored and not all countries with volcanoes have mandated volcano observatories or equivalents. To add to the efforts of volcano observatories, a system of Meteorological Watch Offices, Air Traffic Management Area Control Centres, and nine specialist Volcanic Ash Advisory Centres (VAACs) are
\end{abstract}

P. Lechner $(\bowtie)$

New Zealand Civil Aviation Authority, Wellington, New Zealand e-mail: peter.lechner@caa.govt.nz

\section{A. Tupper}

Australian Bureau of Meteorology, Melbourne, Australia

e-mail: a.tupper@bom.gov.au
M. Guffanti · T. Casadevall

U.S. Geological Survey, Reston, USA

e-mail: guffanti@usgs.gov

T. Casadevall

e-mail: tcasadevall@usgs.gov

S. Loughlin

British Geological Survey, Nottingham, UK

e-mail: sclou@bgs.ac.uk 
responsible for observing, analysing, forecasting and communicating the aviation hazard (airborne ash), using agreed techniques and messages in defined formats. Continuous improvement of the IAVW framework is overseen by expert groups representing the operators of the system, the user community, and the science community. The IAVW represents a unique marriage of two scientific disciplines, volcanology and meteorology, with the aviation user community. There have been many multifaceted volcanic eruptions in complex meteorological conditions during the history of the IAVW. Each new eruption brings new insights into how the warning system can be improved, and each reinforces the lessons that have gone before. The management of these events has improved greatly since the major ash encounters in the 1980s, but discontinuities in the warning and communications system still occur. A good example is a 2014 ash encounter over Indonesia following the eruption of Kelut where the warnings did not reach the aircraft crew. Other events present enormous management challenges-for example the 2010 Eyjafjallajökull eruption in Iceland was, overall, less hazardous than many less publicised eruptions, but numerous small to moderate explosions over several weeks produced widespread disruption and a large economic impact. At the time of writing, while there has been hundreds of millions of US dollars in damage to aircraft from encounters with ash, there have been no fatalities resulting from aviation incidents in, or proximal to volcanic ash cloud. This reflects, at least in part, the hard work done in putting together a global warning system - although to some extent it also reflects a measure of good statistical fortune. In order to minimise the risk of aircraft encounters with volcanic ash clouds, the global effort continues. The future priorities for the IAVW are strongly focused on enhancing communication before, and at the very onset of a volcanic ash-producing event (typically the more dangerous stage), together with improved downstream information and warning systems to help reduce the economic impact of eruptions on aviation.

\section{Keywords}

Volcanic ash • Aviation • Hazard • Global communication

\section{Introduction}

Since the advent of the jet age in the 1960s, there has been a significant and continuing growth in air travel with ever increasing densities of high technology aircraft in limited available civil airspace. Over the same period, the correspondingly increased probability and potentially dire consequence of aircraft encounters with volcanic clouds has become clearly apparent.

Damage to aircraft from volcanic ash cloud encounters can be immediate and long term (Casadevall 1993). As aerospace technology develops, jet-turbine running temperatures have increased markedly seeking increasing thrust and economy. Modern high-bypass jet-turbine 
engines run at temperatures in excess of the melting point of many minerals and silicates. Similarly, the fine tolerances of airframe fabrication, and electrical, hydraulic, and navigation systems can all be compromised by the nature, density, and size of volcanic ash particles. The accretion of volcanic ash silicates on turbine engine blades can, and has, resulted in engine stalling and inability to restart. The accretion or incidence of volcanic ash silicates on and in the airframe can lead to critical interruption of electrical and hydraulic aircraft systems. Even marginal encounters with low density volcanic ash cloud results in accelerated wear and tear on aircraft and engines (International Civil Aviation Organization 2007, Manual on Volcanic Ash, Radioactive Material and Toxic Chemical Clouds, Doc 9691). Any aircraft encounter with a volcanic ash cloud therefore carries both a safety and an economic consequence.

From 1953 to 2009, there have been over 129 reported incidents of aircraft encountering volcanic ash (Guffanti et al. 2010); 79 of these resulted in some physical damage to the aircraft. Of these damaging encounters, 26 can be considered severe, including nine incidents that resulted in loss of in-flight power in one or more engines. Some of the latter have been widely documented, such as the first "all engines out" encounter by a Boeing B747 in 1982 with ash near Indonesia from Galunggung volcano, and the Boeing B747 encounter in 1989 with ash from Redoubt volcano over Alaska (Miller and Casadevall 2000). In contrast some encounters have received little public attention, such as an all-engines failure in a Gulfstream II survey aircraft in 2006 over Papua New Guinea due to an encounter with ash from Manam volcano (Tupper et al. 2007a, b).

From 1953 to 2014, eruptions from 40 volcanoes located in 16 countries have caused damaging encounters of aircraft with ash clouds (Fig. 1). While the most damaging encounters have occurred within $24 \mathrm{~h}$ of eruption onset and/or within $1000 \mathrm{~km}$ of the source, less safety-significant but still economically damaging encounters have occurred at greater distances and extended times (Guffanti et al. 2010).

The potential risk arising from such encounters has often been highlighted by the international

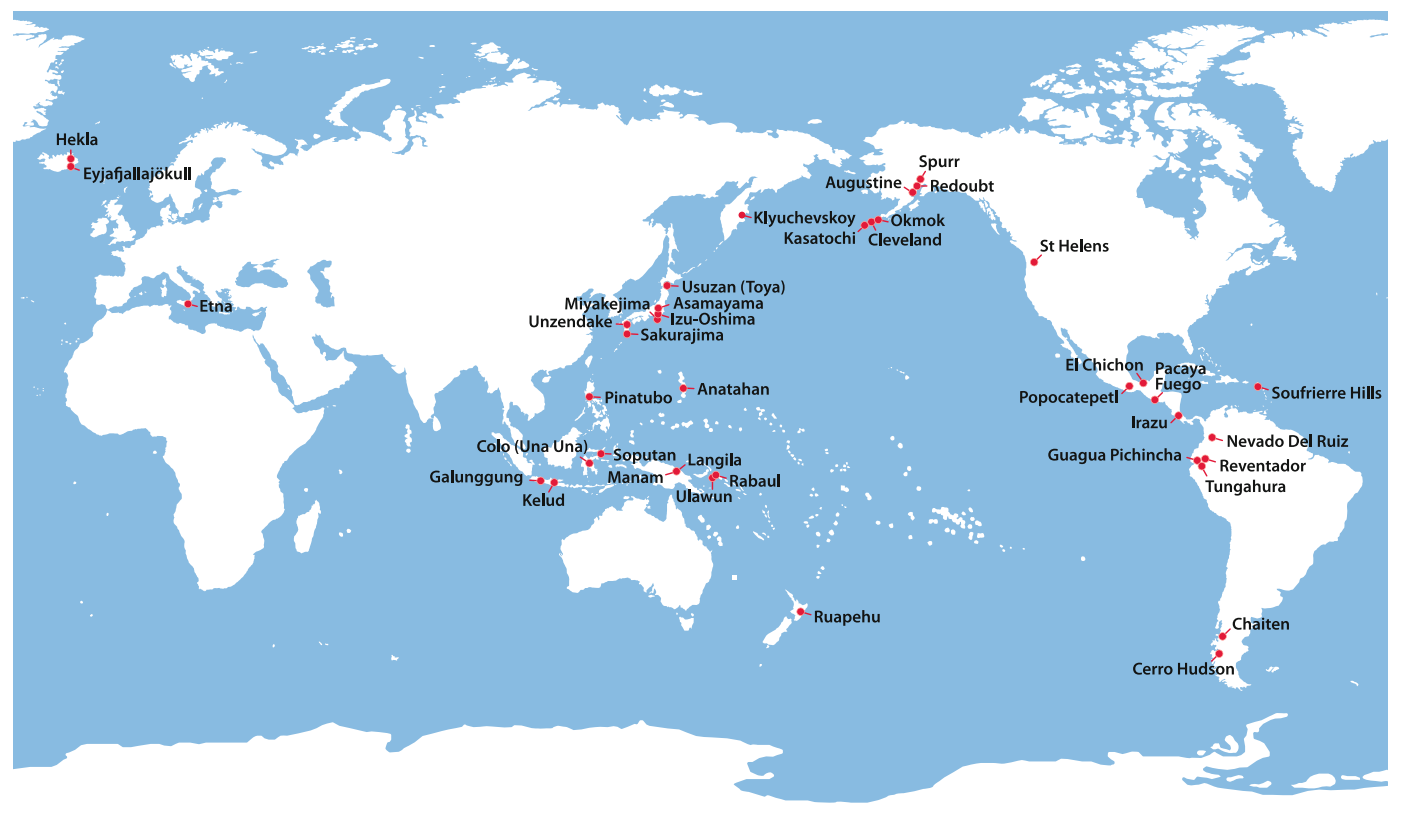

Fig. 1 Map of source volcanoes responsible for damaging encounters of aircraft with ash clouds (modified from Table 7 of Guffanti et al. 2010) 
civil aviation community as a priority area in need of systematic global mitigation and further development of risk reduction measures (International Civil Aviation Organization 2012).

\section{International Airways Volcano Watch}

In response to the demand for globally co-ordinated mitigation of the volcanic ash risks to aviation, the IAVW was established in 1987 by ICAO in close co-ordination with the World Meteorological Organization. Since that time a collaborative approach, led by the IAVW, has matured into a comprehensive worldwide monitoring and notification system (International Civil Aviation Organization 2014a, b).

The IAVW system is an operational programme binding on all ICAO member States (countries) through the Chicago Convention. ${ }^{1}$ The system is made up of three main components:

1. Observing component-this comprises existing international ground-based monitoring and observations (including VONA-Volcano Observatory Notice for Aviation), global satellite based detection and in-flight air reports (VAR-volcanic ash reports) to observe/detect volcanic eruptions and ash clouds and pass the information quickly to appropriate Air Traffic Management Area Control Centres, Meteorological Watch Offices, and VAACs.

2. Advisory component-this comprises the production of advisory products by the VAACs for use by Meteorological Watch Offices and air traffic management Area Control Centres. The Volcanic Ash Advisory (VAA) message and its graphical equivalent (VAG) contain information on the position and current eruptive state of the volcano, the current and expected position of any

\footnotetext{
${ }^{1}$ The Chicago Convention on International Civil Aviation was signed in 1944. Standards and procedures for safe and economic international aviation are set out in detail in 19 Annexes to the Convention.
}

associated volcanic ash cloud, along with relevant contextual information on plume height, observation sources and expectation for the timing of next issue.

3. Warning component - this provides the necessary warnings to aircraft and air traffic management through two types of messages: SIGnificant METeorological information about aviation weather hazards (SIGMETs) that are issued by Meteorological Watch Offices, and NOTices to Air Men (NOTAMs) for changes in airspace status that are issued by Area Control Centres.

The SIGMETs and NOTAMs are based on advisory information supplied by nine designated VAACs, whose aggregate areas of responsibility cover most of the globe. The VAACs in the IAVW system are: Anchorage, Buenos Aires, Darwin, London, Montreal, Tokyo, Toulouse, Washington and Wellington. The approximate VAAC areas of responsibility are shown in Fig. 2.

IAVW services can also be categorised in four areas: (1) monitoring information on the threat, onset, cessation, scale and characteristics of an eruption, (2) monitoring the volcanic ash in the atmosphere, (3) forecasting the expected trajectory and location of the ash cloud, and (4) communicating the information to the users. Essentially, the success of the IAVW system is entirely dependent on requisite information gathering, analyses and prediction, targeted dissemination of information, and the procedural or automatic application of that information.

Before and during a volcanic eruption, the co-ordination and flow of information regarding the (potential) eruption, and the location and forecast position of the volcanic ash cloud is the primary concern. It involves co-operation among all information providers, and between information providers and operational decision makers. Such co-ordination and co-operation requires planning and preparation before an eruption. The primary providers of information include Meteorological Watch Offices, VAACs, volcano observatories, and aircraft in flight, supplemented by information from the research and broader communities. 


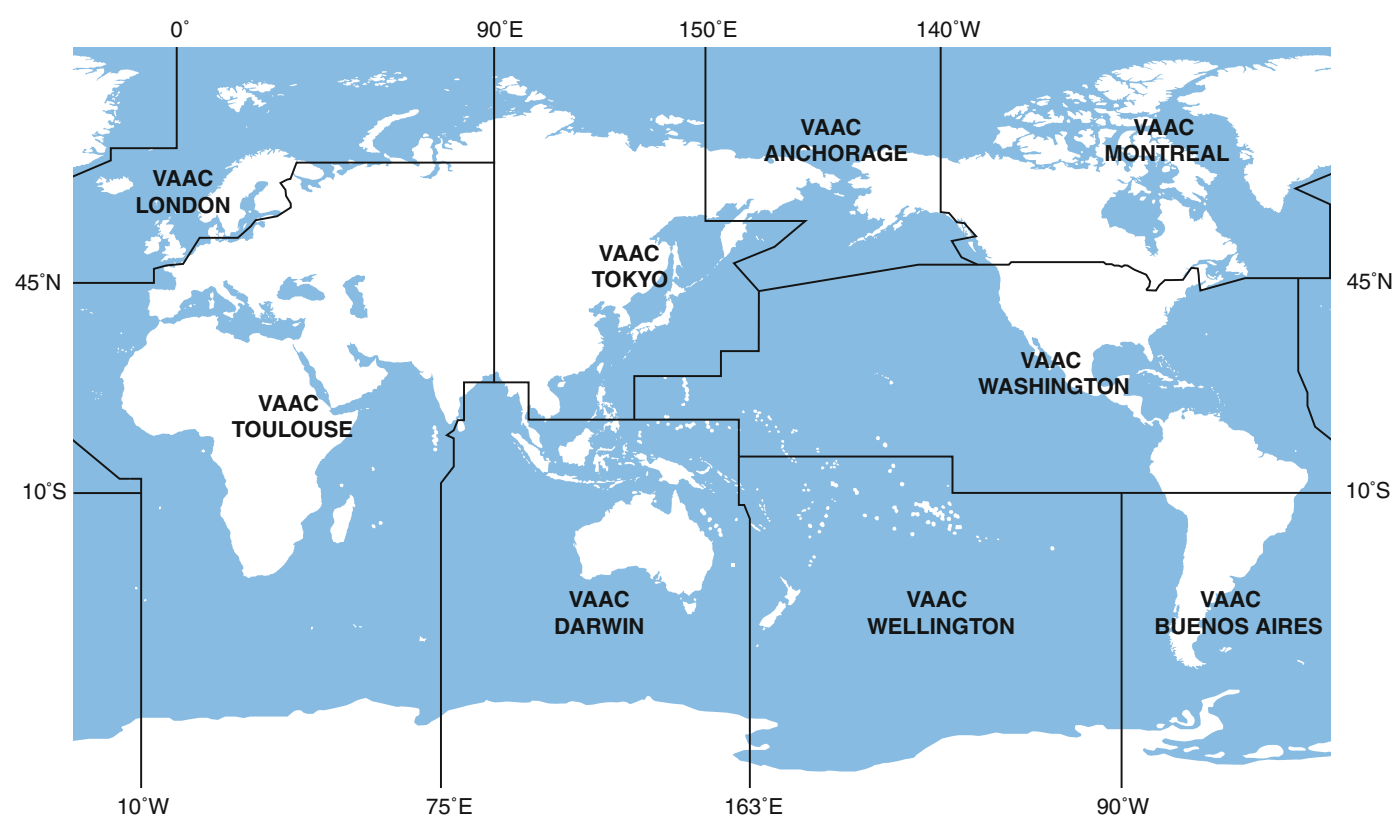

Fig. 2 Areas of responsibility of the nine volcanic ash advisory centres

Users of information (operational decision makers) are Air Traffic Management Systems including Aeronautical Information Services, Air Traffic Control, and Air Traffic Flow Management, private and commercial flight crews, and airline operations centres. Regulatory co-operation between civil aviation authorities and aircraft operators using the information provided is essential for support of the pre-flight planning process, and the in-flight and post-flight decision-making processes; all as part of overall safety risk mitigation. ${ }^{2}$

The lines of communication and responsibility in the IAVW are shown in Fig. 3.

\section{Volcano Monitoring}

Volcano observatories are loosely organised under the banner of the World Organization of Volcano Observatories, a commission of the International Association of Volcanology and the Earth's Interior, itself a member association of ${ }^{2}$ Refer to; ICAO Doc 9974 Flight Safety and Volcanic
Ash. the International Union of Geodesy and Geophysics. Not all volcanoes are monitored and not all countries have volcano observatories.

Volcano observatory staff can detect volcanic unrest, provide eruption forecasts, identify the onset of an eruption, and advise on the evolution and end of an eruption. Ideally these volcano observatories provide guidance on the changing eruption characteristics through time such as plume heights, altitudes of dispersing ash layers in the atmosphere, likely particle size distribution (post initial eruption) and possible mass eruption rates that can be used in numerical dispersion and transport models. Many observatories may analyse eruption products providing information on composition of ash and also gas emissions that impact on aircraft systems. Volcano observatories typically also hold information on past eruptions of a given volcano so they are able to provide likely eruption scenarios and a range of likely eruption parameters, such as possible ash ejection heights, before an eruption occurs. They are also responsible for monitoring ground hazards such as ash fall and volcanic gas dispersal.

Volcano observatories build long-term relationships with civil protection/defence 


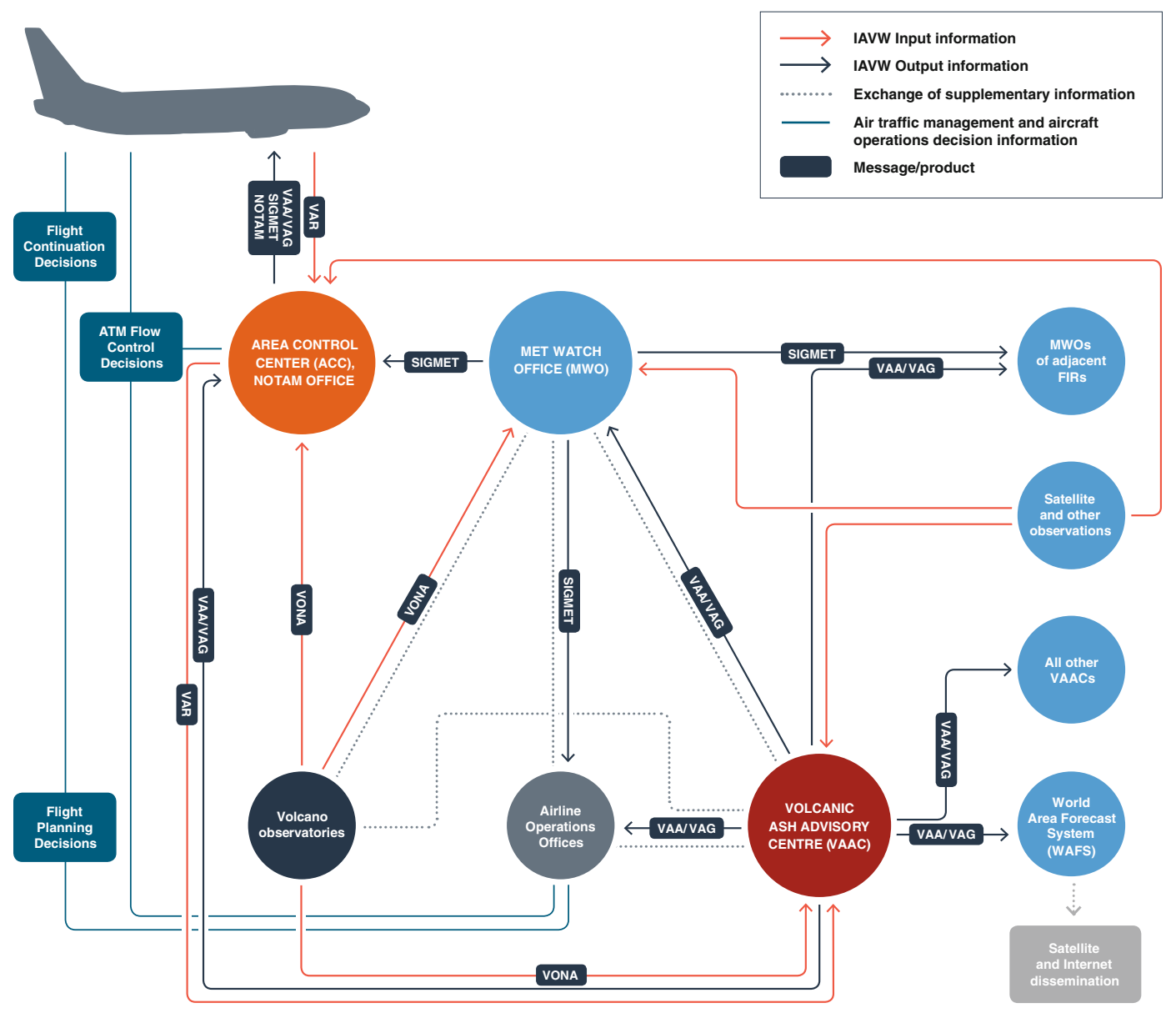

Fig. 3 IAVW system elements and relationships

organisations, local and national authorities, and communities that live around volcanoes. Relationships between VAACs and Meteorological Watch Offices are similarly long-term and strong, given that many observatories run weather stations and have strong links with local meteorologists due to the need to forecast rain-induced lahars (volcanic mud flows), volcanic ash, and gas dispersal. The ascent of magma towards the Earth's surface before an eruption typically generates physical signals that can be detected if appropriate volcano monitoring is in place, thereby allowing eruption forecasting and early warning. Pre-eruptive signals (volcanic unrest) may be detected using a variety of methods, including, but not limited to: volcanic earthquake monitoring using seismometers, ground deformation measurements and observations of hydrologic activity change, gas emissions change monitoring, and steam explosion observations.

The status activity of a volcano is best communicated in a succinct manner to inform decision makers. To assist with this, the international aviation community has established a four-level colour code chart for quick reference to indicate the general state of a given volcano (Table 1). The colour code identifies the state of the volcano (i.e. unrest vs. eruption) but is not intended to represent the status of distal ash in the atmosphere (Guffanti and Miller 2013) or to represent risk to aviation or to people and assets on the ground.

While the international community has developed the colour-code system, it should be noted that, for various reasons, these codes are 
Table 1 ICAO Aviation Colour-Code

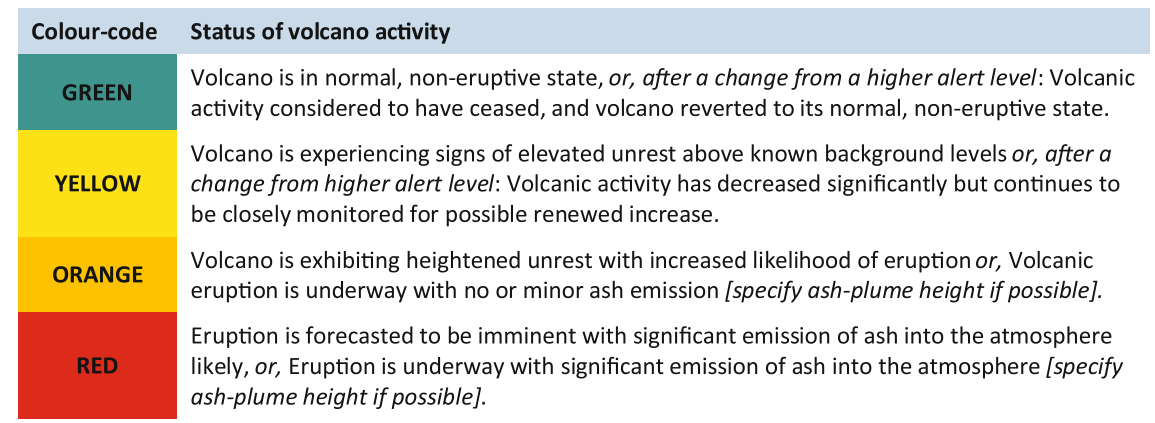

not assigned to all volcanoes. While an international standard, the colour code is currently only formally used by the United States, Russia, New Zealand, and Iceland. The reasons for this vary, but most States not using the colour code indicate difficulties in using international systems in parallel with their own locally accepted and appropriate alert levels for ground hazards. It is also recognised that different colours are associated with adverse situations in different cultures and ethnicities.

In 2008, the IAVW Operations Group introduced a new message format to assist volcanologists in the timely provision of information on the state of a volcano to support the issue of volcanic ash advisories by VAACs, the issue of SIGMET information by Meteorological Watch Offices, and the issue of NOTAM for volcanic ash by Air Traffic (Control) Services. This especially formatted message is referred to as Volcano Observatory Notice for Aviation or VONA (International Civil Aviation Organization 2014a, b). The VONA (or something similar based on discussion and agreement on a case by case basis between the specific agencies involved) is expected to be issued by an observatory when the aviation colour code changes (up or down) or within a colour code level when an ash producing event or other significant change in volcanic behaviour occurs. Two-way discussions are essential between volcano observatories and aviation information providers about the observations and information needed during eruption, formats required, challenges and limitations, as well as an explanation as to how the information will be used and who will receive outputs. For example, the Icelandic Met Office (Iceland's volcano observatory) and the UK Met Office (through the London VAAC) have established a specific format co-designed to suit volcano observatory operating capacities, VAAC needs, and reflect joint experience (Webster et al. 2012). The VONA is a good starting point for such discussions.

\section{The Challenges}

Introducing and continually improving high technology systems to mitigate safety and economic risk from natural events inevitably bring great challenges. For the volcanic risk to aviation these challenges include the detection of volcanic ash cloud, forecasting its dispersion, and the timely and targeted communication of this information, along with system improvement that is well informed by developing scientific understanding.

\subsection{Ash-Cloud Detection and Forecasts}

Today's volcanic ash cloud forecasts, provided by the VAACs, are basic textual and graphical information produced using the output from atmospheric dispersion and transport models. Most of the numerical ash dispersal forecast models utilised by VAACs comprise a 
meteorological model including wind speed and direction, into which volcanic ash is introduced specifying input parameters related to the volcanic source (Eruption Source Parameters). Eruption Source Parameters may include vent location, plume height, eruption duration or start/stop time, mass eruption rate, particle size distribution, vertical distribution of mass with height above the vent and distal fine ash fraction (Mastin et al. 2009). Uncertainty in any of the various source parameters can result in large errors in the resultant volcanic ash cloud forecasts (Webster et al. 2012). Sensitivity analysis can identify the most critical parameters and demonstrate the range of outcomes under different conditions of uncertainty.

Meteorological forecasters evaluate the model outputs before issuing and during the validity of VAA messages. That analysis includes real-time verification of the ash cloud model output against a range of observational resources, principally remote sensing by satellite but also including reports from aircraft and increasingly groundbased sensing such as LIDAR. Post-eruption, model predictions in the distal environment can be compared with observational datasets to examine overall model performance (e.g. Webster et al. 2012).

The current two primary volcanic ash forecast products are the VAA and the SIGMET. The VAACs provide VAA in a text and graphic-based format (VAG) that sets out an analysis of the current position of the ash cloud, and a six, 12 and 18-h forecast location of the ash cloud, setting out position, altitude and thickness using aviation flight level nomenclature. Work has been undertaken informally at each VAAC to provide forecast location of ash cloud out to $24 \mathrm{~h}$. This may become a standard time-step in the future. Meteorological Watch Offices issue volcanic ash cloud SIGMETs based on the guidance provided by the associated VAAC in their respective VAA and VAG products. These SIGMETs are valid for up to $6 \mathrm{~h}$ and describe the current and expected location of the ash cloud within the Flight Information Region or area of responsibility of the Meteorological Watch Offices.
As a supplementary service, at time of writing, the European and North Atlantic regions use forecast ash cloud concentration charts issued alongside official VAAC products. Such charts, depicting forecast ash concentration were first provided to users in April 2010 in response to the Eyjafjallajökull volcanic event. It is important to note that there are currently no globally agreed standards and procedures for the production, provision, and use of concentration charts (Guffanti and Tupper 2015).

\subsection{Communications}

In elementary terms, the IAVW system is required to provide volcanic ash cloud information to airline operators and Air Traffic Management system providers who then pass the information to airline dispatchers and pilots. Figure 3 depicts the information flow following a volcanic eruption and identifies participants in the provision of volcanic ash cloud information.

In practice, and despite some excellent initiatives to improve it, communication can fail at any stage. For many significant aviation encounters, aircraft crew members had no knowledge of the eruption encountered despite it being evident to people on the ground - this was the case recently with an aircraft experiencing a damaging encounter with ash from Kelut, Indonesia, $6 \mathrm{~h}$ after the 13 February 2014 eruption (airline sources, unpublished communication, 2014). The worst known example occurred in 1991 when there were at-least sixteen in-flight encounters with volcanic ash from Pinatubo, in the Philippines. These encounters occurred despite extensive information being available. Casadevall et al. (1996) noted that the response within the Philippines was relatively effective, but the international response was not, as summarised:

...information and warnings about the hazard of
volcanic ash either did not reach appropriate offi-
cials in time to prevent these encounters or that
those pilots, dispatchers, and air traffic controllers
who received this information were not sufficiently
educated about the volcanic ash hazard to know
what steps to take to avoid ash clouds... the key to 
communicating information about volcanic eruptions in a timely and readily understandable form is to involve all interested groups (geologists, meteorologists, pilots, and air traffic controllers) in the development of information and to streamline the distribution of this information between essential parties....

Other documented examples include the Manam eruptions during 2004-05 in Papua New Guinea where a large number of pilot reports of volcanic activity collected in flight were not passed on outside the airline involved, regardless of international requirements (Tupper et al. 2007a, b). Conversations with the air traffic management community have also indicated that air traffic controllers are often too busy to pass on messages that they believe have a lower priority than managing the separation of aircraft (Tupper, personal communication, 2014).

When communications are working well, initial reports of volcanic ash can result in useful information being delivered to the end user. In most cases, information about a volcanic ash cloud will be provided to the pilot, either in flight, or during pre-flight planning, in the form of SIGMETs, NOTAMs, reports from pilots, or VAA/VAG. Each of these products is distinct in format and content, but all can provide information regarding the location of volcanic ash cloud. It is critically evident that all of these products must be consistent in their overall message. When the situation is changing rapidly, that can be extremely challenging.

The 18 August 2000 eruption of Miyakejima, Japan, illustrated this point (Tupper 2012). At least four non-Japanese aircraft encountered the cloud, with two sustaining significant damage. The eruption was sudden, but there was very strong awareness amongst domestic and some foreign airlines of the potential for activity at the volcano. The eruption was well observed, and the speed of response by Japanese authorities was exceptional. Nevertheless, there were some minor communication issues at several stages in the warning chain, resulting in inconsistencies in the information available, particularly during the rapidly developing early stages of the eruption.

To illustrate the potential differences of estimated volcanic ash cloud height in various real-time warnings, Fig. 4 sets out the ash cloud heights stated in VAA, SIGMET, and NOTAM, with respect to their issue time and validity, against the post eruption evaluation of the approximate real volcanic ash cloud height for the 2000 Miyakejima event. The times and approximate altitudes of four confirmed aircraft encounters with the cloud are shown. During the critical first half hour of the eruption, the VAA and then consequent warnings responded to

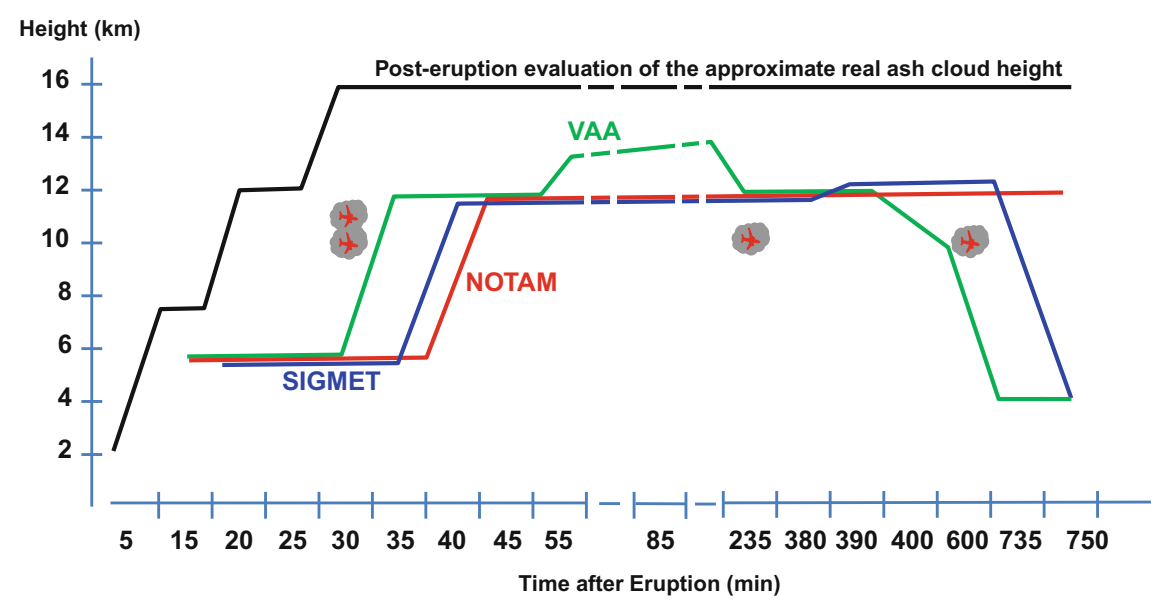

Approximate time and altitude of reported aircraft encounter with volcanic ash cloud

Fig. 4 Schematic showing volcanic ash cloud height as set out in various real-time warnings along with approximate real ash cloud height for the 2000 Miyakejima event, over approximate time after eruption. After Tupper et al. (2004) 
multiple, and in some cases time-lagged observations and information loops. The two early encounters occurred before a concurrent height of the eruption was reflected in the warnings. The actual warning response was relatively good for this eruption, but the schematic illustrates the complexity of messaging, in a fast changing environment, particularly with multiple warning types.

Getting the official communication for warnings right can be made easier, but can also be complicated by non-official communications. In recent years, the rise of social media, enhanced remote communications, and omnipresent digital photography has meant that unofficial eruption and hazard notifications have become almost expected. Operational centres can and do use this to their advantage, particularly for early alerting. However observers can be mistaken-for example during the eruption at Bardarbunga Iceland in 2014 there were Twitter reports of an eruption ash cloud based on web cam pictures but it was in fact a dust storm from a nearby sandur plain. Another downside is the amount of 'chatter' and the potential for conflicting messaging. Nevertheless, the necessity for public engagement during an event has also risen. The relative level of safety risk of events is also not necessarily reflected in the attention that particular eruptions get in public.

As a result of the avalanche of non-official communications during volcanic events, VAACs and Meteorological Watch Offices endeavour to authenticate all incoming information to establish the reliability and weighting of such information. For example, in 2010, earth scientists and atmospheric scientists in Iceland and the UK enhanced their relationships in a number of ways, including through visits between operational institutions (VAAC at the UK Met Office and Iceland's volcano observatory, the Icelandic Met Office) to better understand processes and working practices used by the other organisation. In parallel, civil protection authorities in the UK sought information and advice about impacts to the UK through UK national research institutions, who in turn consulted Icelandic scientists including the Icelandic Met Office.

In order to support both aviation and civil protection sectors and to facilitate strategic science, a memorandum of understanding was established between the UK and Iceland to facilitate the flow of information between nations, and to enable wider management of the impacts of cross-border hazards and co-ordination of distal observations of volcanic ash cloud. This memorandum of understanding now underpins long-term productive cross-disciplinary research and relationships. The Icelandic Met Office with the National Commissioner of Icelandic Police (Iceland's Civil Protection) continue to make a great deal of data and information available in close to real time during volcanic unrest and eruptions (including that on social media) to enhance communication across sectors.

\subsection{Science Challenges}

Operational enhancements will continue to need wide scientific development work and expansion of the understanding of the full volcanic ash hazard and risk to aviation.

The central theme of scientific concern is how to accurately determine the constituents (solid particles, gases, and aerosols), density, and three-dimensional shape of a volcanic cloud at particular times and locations. Understanding engine and airframe tolerances to ash ingestion and gas effects will better inform the operational risk management of airlines.

Reducing uncertainties in ash reporting and plume modelling is expected to eventually provide critical warning system enhancements in the future.

During volcanic eruptions, a number of toxic gases may be emitted in addition to ash; these include sulphur dioxide $\left(\mathrm{SO}_{2}\right)$, hydrogen fluoride (HF), and hydrogen sulphide $\left(\mathrm{H}_{2} \mathrm{~S}\right)$ amongst many others. Each of these gases has different atmospheric dispersion properties, and so gas clouds may be found coincident or separate from volcanic ash clouds. Of these gases, $\mathrm{SO}_{2}$ is of particular importance as it may be emitted in large quantities and potentially has significant health effects, as well as longer term effects on aircraft. Further engineering and science work is needed to fully understand this area and reflect any advances in the IAVW system.

In pursuing these objectives the aviation community has been well supported for many years by 
the science community, including the World Meteorological Organization and the International Union of Geodesy and Geophysics, member associations, and many dedicated individuals.

Particular support in contributing to and co-ordinating these scientific endeavours in support of the ICAO IAVW will continue to be provided by the WMO Sponsored Volcanic Ash Advisory Group and VAAC Best Practices workshops. Supplementing this, the periodic WMO sponsored volcanic ash science meeting is expected to provide the academic forum for reporting of developments and scientific collaboration.

In supporting this growing area of work, future science investment will be essential to continue developing the IAVW.

\section{Warning System Enhancements}

The eruption of Iceland's Eyjafjallajökull volcano during March to May 2010 demonstrated again the vulnerability of aviation to volcanic eruptions. According to an analysis by Oxford Economics (2015), more than 100,000 commercial flights were cancelled during the Eyjafjallajökull volcano eruptive phase, and US $\$ 4.7$ billion in global GDP was lost. The report estimated the gross loss to airlines worldwide at US $\$ 2.6$ billion due to this single volcanic event.

Later, in 2010 and in response to the Eyjafjallajökull episode (International Civil Aviation
Organization 2013a), ICAO established an International Volcanic Ash Task Force as a multidisciplinary global group to further develop and co-ordinate work related to volcanic ash. Before it concluded its work in 2012, it addressed issues related to air traffic management, aircraft airworthiness, aeronautical meteorology, and volcanological and atmospheric sciences. The Task Force identified further work to be undertaken, by existing bodies such as the IAVW Operations Group and collaborative best practice development amongst the nine VAACs, co-ordinated by the WMO (Guffanti and Tupper 2015).

Also of significance, over the last decade ICAO has gradually developed and begun implementing a Global Air Navigation Plan (ICAO 2013b Doc 9750, 2013-2028) as an overarching air navigation framework, including key civil aviation policy principles to assist regions and States with the preparation of their Regional and State air navigation plans.

The objective of the Global Air Navigation Plan is to increase airspace capacity and improve efficiency of the global civil aviation system while improving, or at least maintaining safety. The Plan includes an upgrade framework, and guidelines for associated technology development covering communications, surveillance, navigation, information management, meteorology and avionics.

The Plan reflects all of the science, communications and operational recommendations of the International Volcanic Ash Task Force 4th

Table 2 Enhancement of Volcanic Ash Risk Mitigation-Excerpts from the ICAO Global Air Navigation Plan (Abridged) with supporting and progress commentary

\begin{tabular}{l|l|l}
\hline $\begin{array}{l}\text { Global air navigation } \\
\text { plan module }\end{array}$ & Commentary & Progress \\
\hline $\begin{array}{l}\text { Completion by } 2018 \\
\begin{array}{l}\text { Implement widely } \\
\text { collaborative processes }\end{array}\end{array}$ & $\begin{array}{l}\text { Acceptable developments should take into } \\
\text { account the needs of all directly involved }\end{array}$ & $\begin{array}{l}\text { Common views have been established on } \\
\text { the collaborative treatment of volcanic ash } \\
\text { cloud extending across different Flight } \\
\text { Information Regions and VAAC areas }\end{array}$ \\
\hline $\begin{array}{l}\text { Increase the provision of } \\
\text { Volcano Observatory } \\
\text { Notices to Aviation }\end{array}$ & $\begin{array}{l}\text { Not all State Volcano Observatories are } \\
\text { issuing VONA }\end{array}$ & $\begin{array}{l}\text { State Volcano Observatories have been } \\
\text { encouraged to issue the VONA. The } \\
\text { number of States doing so is increasing }\end{array}$ \\
\hline $\begin{array}{l}\text { Develop information } \\
\text { confidence levels }\end{array}$ & $\begin{array}{l}\text { This work responds to a request from the } \\
\text { International Air Transport Association } \\
\text { (IATA) }\end{array}$ & $\begin{array}{l}\text { VAAC provider States are actively } \\
\text { developing confidence level concepts from } \\
\text { both a science and operational standpoint }\end{array}$
\end{tabular}


Table 2 (continued)

\begin{tabular}{|c|c|c|}
\hline $\begin{array}{l}\text { Global air navigation } \\
\text { plan module }\end{array}$ & Commentary & Progress \\
\hline \multicolumn{3}{|l|}{ Completion by 2023} \\
\hline $\begin{array}{l}\text { Enhance the provision } \\
\text { of SIGMETs }\end{array}$ & $\begin{array}{l}\text { A large volcanic ash cloud over congested, } \\
\text { multi-State areas can result in multiple } \\
\text { SIGMET information messages, all being } \\
\text { in effect at the same time }\end{array}$ & $\begin{array}{l}\text { Work is underway better support MWO } \\
\text { responsibilities to issue SIGMET } \\
\text { Work is also underway to develop a } \\
\text { regional approach to the issue of SIGMET }\end{array}$ \\
\hline $\begin{array}{l}\text { Transition to all-digital } \\
\text { format }\end{array}$ & $\begin{array}{l}\text { Volcanic cloud information needs to be } \\
\text { provided in a digital form to support } \\
\text { ingestion directly into flight planning and } \\
\text { flight management systems }\end{array}$ & $\begin{array}{l}\text { A large area of work is under way as part } \\
\text { of the ICAO Meteorology Panel set of } \\
\text { projects to support the development of } \\
\text { data-centric meteorological information in } \\
\text { GML/XML form }\end{array}$ \\
\hline $\begin{array}{l}\text { Increase Volcanic } \\
\text { Advisory message } \\
\text { frequency and time steps }\end{array}$ & $\begin{array}{l}\text { Operators need frequent updates of } \\
\text { volcanic ash information especially in } \\
\text { congested airspace and around constrained } \\
\text { airports }\end{array}$ & $\begin{array}{l}\text { Dynamic provision of forecast data is being } \\
\text { considered as part of the overall move to } \\
\text { data-centric meteorological products }\end{array}$ \\
\hline $\begin{array}{l}\text { Continued } \\
\text { improvements in } \\
\text { observing networks }\end{array}$ & $\begin{array}{l}\text { Reliable and granular observation of } \\
\text { meteorological phenomena including } \\
\text { volcanic ash is pivotal in improving } \\
\text { forecast products }\end{array}$ & $\begin{array}{l}\text { The expansion of ground-based networks, } \\
\text { satellite platforms and sensors, and } \\
\text { airborne sampling will continue building } \\
\text { on existing accomplishments }\end{array}$ \\
\hline \multicolumn{3}{|l|}{ Completion by 2028} \\
\hline $\begin{array}{l}\text { Implementation of } \\
\text { Now-casts }\end{array}$ & $\begin{array}{l}\text { Aircraft operating at up to } 1000 \mathrm{~km} / \mathrm{h} \text { need } \\
\text { to know the current location of a volcanic } \\
\text { ash cloud at any given time }\end{array}$ & $\begin{array}{l}\text { It is expected that a three-dimensional } \\
\text { representation of the current or near-current } \\
\text { volcanic ash boundaries could eventually } \\
\text { be made available and extracted by the user } \\
\text { as required }\end{array}$ \\
\hline $\begin{array}{l}\text { Implementation of } \\
\text { Probabilistic forecasts }\end{array}$ & $\begin{array}{l}\text { Current volcanic ash forecasts are } \\
\text { deterministic forecasts. They are a yes/no } \\
\text { forecast, with respect to the depiction of the } \\
\text { airspace impacted by discernible }{ }^{\mathrm{a}} \text { volcanic } \\
\text { ash }\end{array}$ & $\begin{array}{l}\text { Probabilistic forecasts will provide } \\
\text { decision makers with an assessment of all } \\
\text { the likelihoods of risk of occurrence } \\
\text { exceeding a defined magnitude }\end{array}$ \\
\hline
\end{tabular}

Completion after 2028

\begin{tabular}{l|l|l}
\hline $\begin{array}{l}\text { Other contaminant } \\
\text { forecasts }\end{array}$ & $\begin{array}{l}\text { There is a need to expand the warning } \\
\text { services to other toxic emissions from } \\
\text { volcanic eruptions }\end{array}$ & $\begin{array}{l}\text { This issue is currently being studied by } \\
\text { both ICAO and WMO experts }\end{array}$ \\
\hline $\begin{array}{l}\text { Trajectory based } \\
\text { operations }\end{array}$ & $\begin{array}{l}\text { Integration of volcanic cloud now-casts } \\
\text { and forecasts, combined with the use of } \\
\text { probabilistic forecasts to address } \\
\text { uncertainty, is expected to significantly } \\
\text { reduce the effects of volcanic cloud on air } \\
\text { traffic flow }\end{array}$ & $\begin{array}{l}\text { The meteorological and air traffic } \\
\text { management communities are starting to } \\
\text { work more closely on this objective }\end{array}$ \\
\hline $\begin{array}{l}\text { Development of Index } \\
\text { levels for aircraft ash } \\
\text { tolerances }\end{array}$ & $\begin{array}{l}\text { Aircraft operators increasingly need } \\
\text { quantitative volcanic ash forecasts to take } \\
\text { advantage of yet to be specified aircraft and } \\
\text { engine limits. }\end{array}$ & $\begin{array}{l}\text { The development of a volcanic ash index } \\
\text { for ash/gas tolerances of various types of } \\
\text { engine/aircraft combinations is in the very } \\
\text { initial stages of engineering review and } \\
\text { concept design. }\end{array}$ \\
\hline $\begin{array}{l}\text { Airborne detection } \\
\text { equipment }\end{array}$ & $\begin{array}{l}\text { A few basic systems to alert pilots to the } \\
\text { distal presence of volcanic ash are under } \\
\text { evaluation }\end{array}$ & $\begin{array}{l}\text { To allow operators to take advantage of } \\
\text { tactical on-board volcanic ash detection } \\
\text { equipment, new air traffic management } \\
\text { processes will need to be developed }\end{array}$ \\
\hline
\end{tabular}

${ }^{a}$ Discernible ash is defined as "volcanic ash detected by defined impacts on/in aircraft or by agreed in-situ and/or remote-sensing techniques"; Visible ash is defined as "volcanic ash observed by the human eye" and not defined quantitatively by the observer 
Meeting (2012) to further develop and co-ordinate work related to volcanic ash risk mitigation. The main approaches from these initiatives to be implemented by the IAVW Operations Group are set out chronologically in Table 2.

In essence, the Plan calls for the enhancement of collaborative processes in the observation and provision of information, better land and aircraftbased volcano and ash observations, the introduction of confidence levels to forecast information, increased frequency of information, introduction of probabilistic forecasts, and the introduction and use of data on aircraft ash tolerances.

\section{Conclusion}

There is no doubt that future volcanic eruptions, coupled with certain meteorological conditions, have the potential to cause significant disruptions to air transport (Sammonds et al. 2011).

The ongoing development of the IAVW system continues to reveal significant challenges, some of which may remain unresolved. Enacting a fit-for-purpose warning network that brings volcanic hazard warnings into the aircraft cockpit requires the bridging of gaps between two sciences (volcanology and meteorology) in order to understand the hazard, to knit the operational parts of those sciences together in a single warning system, and then to connect with operations in the time and resource-critical aviation industry.

Fortunately, and arguably due in large part to the IAVW system, there have been no fatalities associated with aircraft operations proximal to volcanic ash clouds. However, where the eruption is forecast, warned for, resulting volcanic ash clouds tracked, and with communications procedures in place and followed, experience shows that aircraft are still not always able to avoid volcanic ash clouds. Naturally, where science or communications cannot provide usable information, the operational risk rises.

The objective remains to provide increasingly granular and robust information that will allow aircraft to operate, safely and economically, proximal to volcanic ash in the atmosphere. While much has been achieved, there is more to do, in procedures, science, engineering, and in practical communications. Without good warning system communications, fully informed by the social sciences that assist in the 'uptake' of the message, and by robust, reliable operational practices, the fruit of science and policy development will remain compromised.

Lastly, because the advent of the IAVW has brought the meteorological and aviation communities much closer to the volcanological community, there is an exciting opportunity to bring potentially useful practices further into the combined geophysical hazards space. For example, volcanic tsunami, lahar warnings, ash fall, and even rainfall induced lava dome collapses, are all areas where the two fields will need to work together well to produce enhanced warning and communication services.

\section{References}

Casadevall TJ (1993) Volcanic hazards and aviation safety: lessons of the past decade. Flight safety foundation, flight safety digest, May 1993

Casadevall TJ, Delos Reyes PJ, Schneider DJ (1996) The 1991 Pinatubo eruptions and their effects on aircraft operations. In: Newhall CG, Punongbayan RS (eds) Fire and mud: eruptions and lahars of Mount Pinatubo, Philippines. Philippines Institute of Volcanology and Seismology \& University of Washington Press, Quezon City \& Seattle, pp 625-636

Guffanti M, Miller TP (2013) A volcanic activity alert-level system for aviation-review of its development and application in Alaska. Nat Hazards 69:1519-1533. doi:10.1007/s11069-013-0761-4

Guffanti M, Tupper A (2015) Volcanic ash hazards and aviation risk. In: Pappale $\mathrm{P}$ (ed) Volcanic hazards, risks and disasters. Elsevier, Amsterdam, pp 87-108

Guffanti M, Casadevall T, Budding K (2010) Encounters of aircraft with volcanic ash clouds: a compilation of known incidents, 1953-2009. USGS data series 545

ICAO (2012) International Volcanic Ash Task Force, 4th meeting Montreal, Canada, June (2012), meeting report

International Civil Aviation Organization (2007) Doc 9691-manual on volcanic ash, radioactive material and toxic chemical clouds

International Civil Aviation Organization (2010) Journal, vol 65, No 4. Eyjafjallajoull's Aftermath

International Civil Aviation Organization (2012) Doc 9974, Flight safety and volcanic ash. Available via http://www.icao.int/publications/Documents/9974_en. pdf. Accessed 1 Dec 2014

International Civil Aviation Organization (2013a) Journal, vol 68, No 1. Heeding Eyjafjallajoull's Lessons

International Civil Aviation Organization (2013b) Doc 9750, 4th edn. 2013-2028 Global Air Navigation Plan 
International Civil Aviation Organization (2014a) International airways volcano watch operations group eighth meeting Melbourne, Australia, February (2014) Roadmap for international airways volcano watch (IAVW) in Support of International Air Navigation

International Civil Aviation Organization (2014b) Doc 9766- Handbook on the international airways volcano watch (IAVW). Available via http://www.icao. int/safety/meteorology/iavwopsg/Pages/default.aspx. Accessed 1 Dec 2014

Mastin LG, Guffanti M, Servranckx R, Webley P, Barsotti S, Dean K, Durant A, Ewert JW, Neri A, Rose WI, Schneider D, Siebert L, Stunder B, Swanson G, Tupper A, Volentik A, Waythomas CF (2009) A multidisciplinary effort to assign realistic source parameters to models of volcanic ash-cloud transport and dispersion during eruptions. J Volcanol Geotherm Res 186(1-2): 10-21. doi:10.1016/j.jvolgeores.2009.01.008

Miller TP, Casadevall TJ (2000) Volcanic ash hazards to aviation. In: Sigurdsson H (ed) Encyclopedia of volcanoes. Academic Press, San Diego, pp 915-930

Oxford Economics - the economics of air travel restrictions due to volcanic ash. Prepared for AirBus Industries. https://www.oxfordeconomics.com/myoxford/projects/129051. Accessed 1 June 2015

Sammonds, McGuire, Edwards (2011) Volcanic hazard from Iceland-analysis and implications of the
Eyjafjallajoulls eruption, 2011 UCL Institute for Risk and Disaster Management. Operations Group

Tupper A (2012) Managing diffuse eruption clouds - the experiences of 2010-11 and the results of the IVATF. 28th congress of the aeronautical sciences

Tupper A, Kamada Y, Todo N, Miller E (2004) Aircraft encounters from the 18 August 2000 eruption at Miyakejima, Japan. In: Second international conference on volcanic ash and aviation safety. Office of the federal coordinator for meteorological services and supporting research, Alexandria, Virginia, USA, pp 1:5-1:9

Tupper A, Guffanti M, Rose B, Patia H, Richards M, Carn S (2007a) The "Gulfstream incident"; Twin-engined flame-out over the Papua New Guinea highlands. In: 4th international work-shop on volcanic ash, Rotorua, New Zealand, 26-30 Mar 2007 [Proceedings]: World Meteorological Organization, Commission for Aeronautical Meteorology, 6 pp.http://www.caem.wmo.int/ moodle/course/info.php?id=27. Accessed 17 June 2015

Tupper A, Itikarai I, Richards MS, Prata F, Carn S, Rosenfeld D (2007b) Facing the challenges of the international airways volcano watch: the 2004/05 eruptions of Manam, Papua New Guinea. Weather Forecast 22(1):175-191

Webster HN et al (2012) Operational prediction of ash concentrations in the distal volcanic cloud from the 2010 Eyjafjallajökull eruption. J Geophys Res 117: D00U08. doi:10.1029/2011JD016790
Open Access This chapter is licensed under the terms of the Creative Commons Attribution 4.0 International License (http://creativecommons.org/licenses/by/4.0/), which permits use, sharing, adaptation, distribution and reproduction in any medium or format, as long as you give appropriate credit to the original author(s) and the source, provide a link to the Creative Commons license and indicate if changes were made.
The images or other third party material in this chapter are included in the chapter's Creative Commons license, unless indicated otherwise in a credit line to the material. If material is not included in the chapter's Creative Commons license and your intended use is not permitted by statutory regulation or exceeds the permitted use, you will need to obtain permission directly from the copyright holder. 